\title{
Analisis Kekuatan Flange Valve Akibat Pengaruh Bolt Torque pada Kondisi Pressure dan Temperature Berbeda dengan Metode Finite Element Analysis
}

\author{
Meri Rahmi ${ }^{1}$, Suliono ${ }^{2}$, Delffika Canra ${ }^{3}$, Rachmatullah ${ }^{4}$, Yusuf Nur Rohmat ${ }^{5}$, Dedi Suwandi ${ }^{6}$ \\ Teknik Mesin, Politeknik Negeri Indramayu, Jl. Lohbener Lama No.08, Indramayu, 45252 \\ Email: meri@polindra.ac.id
}

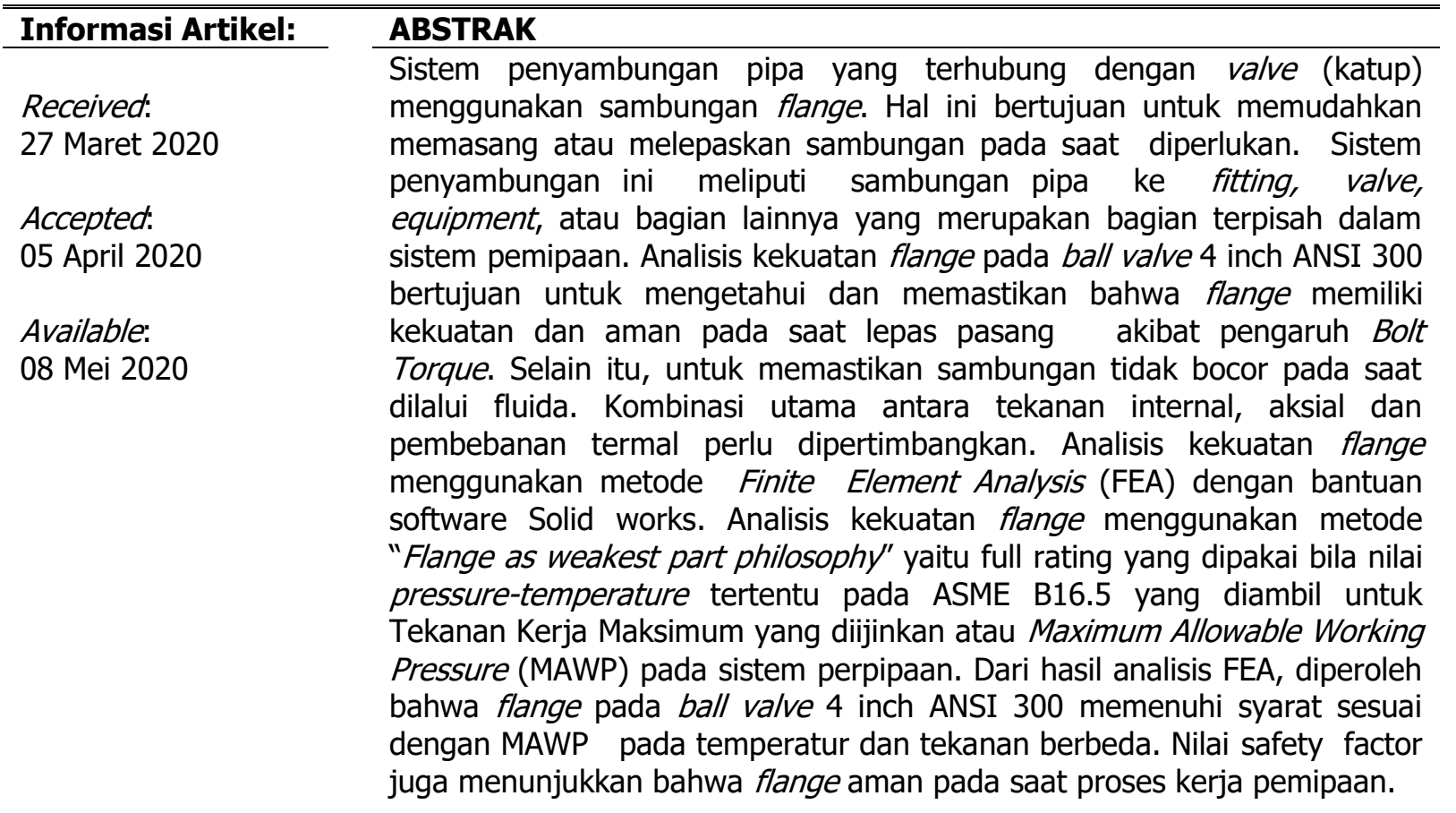

\section{Kata Kunci:}

Flange Bolt

Torques

Valve

Finite Element

Analysis (FEA)

Maximum Allowable

Working Pressure

(MAWP)

\begin{abstract}
Pipe connecting system that is connected with a valve using a flange connection. This aims to make it easier to install or disconnect when needed. This connection system includes pipe connections to fittings, valves, equipment, or other parts which are separate parts of the piping system. The analysis of the flange strength on the 4 inch ball valve ANSI 300 aims to determine and ensure that the flange has strength and is safe at the time of tide due to the influence of the torque bolt. In addition, to ensure the connection does not leak when the fluid is passed. The main combination between internal, axial pressure and thermal loading needs to be considered. Flange strength analysis using Finite Element Analysis (FEA) method with use of Solid works software. The analysis of flange strength uses the method of "Flange as weakest part philosophy", namely the full rating used when the value of a certain pressure-temperature on ASME B16.5 is taken for the Maximum Allowable Working Pressure (MAWP) in the piping system. From the results of the FEA analysis, it was found that the flange on the 4 inch ANSI 300 ball valve meets the requirements according to MAWP at different temperatures and pressures. The value of the safety factor also shows that the flange is safe during the piping work process.
\end{abstract}




\section{Pendahuluan}

Flange atau sambungan flens yang dibaut dengan gasket konvensional banyak digunakan untuk menghubungkan bejana tekan dan pipa dalam industri proses, minyak dan gas. Kinerja flange terlihat pada kekuatan sambungan. Evaluasi integritas dan kinerj sambungan perlu dilakukan terutama jika mendapat bebena kerja yang melebihi batas dalam sebuah sistem. Perlu dicatat bahwa aturan desain yang tersedia untuk sambungan flange memiliki standar dan kode dalam desain internasional terutama berkaitan dengan kekuatan. Tetapi ini tidak cukup menjadi jaminan bahwa sambungan flange tersebut kuat [1][2].

Baut merupakan koneksi flange yang biasa digunakan untuk mendukung dan sebagai koneksi yang menghubungkan beberapa bagian dalam sistem pemipaan. Banyak dari koneksi ini mungkin perlu analisis dan dirancang dengan pembebanan statis dan fatigue dengan gaya aksial gabungan dan tekukan. Couchaux [3] menyimpulkan bahwa kekuatan tarik sambungan flange dengan menggunakan baut dengan berbagai variasi jumlah baut menjadi enam dengan metode analitik dan analisis untuk model tertentu valid dan kuat sebagai sambungan.

Abid [4] secara eksperimental telah mempelajari kinerja dan kondisi sambungan gasket pada flange di bawah baut pada saat operasi dengan kondisi yang berbeda dari perspektif mekanis yaitu tekanan internal gabungan ditambah pembebanan aksia, tekanan internal gabungan ditambah beban lentur pada temperatur $100^{\circ} \mathrm{C}$. Namun, aplikasi pemuatan termal belum dianggap saat ini, karena kompleksitas aplikasi selama studi eksperimental. Hasilnya menunjukkan bahwa berdasarkan berbagai kombinasi beban dinyatakan aman akan tetapi tidak aman pada kondisi batas maksimum operasional.

Dalam aplikasi dunia nyata, sambungan pipa yang dibaut akan mengalami perubahan karena beban struktural dan termal yang berbeda, bahkan akan mengalami guncangan termal dan tekanan pada aplikasi kelas atas. Penelitian Rahmi [5] menyimpulkan bahwa hasil analisis perbedaan tekanan fluida pada ball valve 4 inch ANSI 300 dengan kondisi full closed dan open closed dan temperatur $425^{\circ} \mathrm{C}$ tidak signifikan [6]. Perbedaan tekanan fluida antara kondisi full closed dengan full open hanya 0.01psi. Penelitian Rahmi [7], tentang kekuatan ball valve 4 inch ANSI 300 akibat tekanan fluida pada kondisi jenis temperatur $-29.5^{\circ} \mathrm{C}, 25^{\circ} \mathrm{C}$ dn $425^{\circ} \mathrm{C}$ menyatakan bahwa valve dinyatakan kuat dan aman dengan safety factor melebihi batas minimum yang diizinkan untuk sistem pemipaan.

Khusus untuk flange pada ball valve 4 inch ANSI 300, belum pernah dilakukan Finite Element Analysis (FEA). Penelitian ini bertujuan untuk analisis kekuatan flange pada sistem pemipaan ball valve 4 inch ANSI 300 pada kondisi tekanan dan temperatur berbeda. Tekanan atau beban torsi pada baut mengikuti ASME B16.5 yang diambil sebagai Tekanan Kerja Maksimum yang diijinkan atau Maximum Allowable Working Pressure (MAWP).

Oleh karena itu, dengan mengingat pentingnya kinerja sambungan baut pada kondisi perbedaan tekanan dan temperatur, pembebanan aksial dan termal menggunakan metode Finite Element Analysis (FEA). Disimpulkan bahwa metodologi yang dikembangkan dapat memberikan dasar untuk semua ukuran dan kelas di bawah kondisi operasi gabungan yang berbeda. 
Analisis Kekuatan Flange Valve Akibat Pengaruh Bolt Torque pada Kondisi Pressure dan Temperature Berbeda dengan Metode Finite Element Analysis

\section{METODOLOGI PENELITIAN}

Metode untuk analisis Flange Ball Valve 4 inch ANSI 300 adalah Finite Element Analysis (FEA) dengan bantuan software Solid works. Beberapa hal penting untuk analisis FEA antara lain:

\subsection{Model Geometri, Model FEA dan Meshing}

Model yang digunakan untuk analisis kekuatan flange karena pengaruh tekanan dalam sistem dan adanya pengaruh Bolt Torque sudah disederhanakan untuk memudahkan dalam simulasi analisis [8][9]. Model dapat dilihat pada Gambar 1.

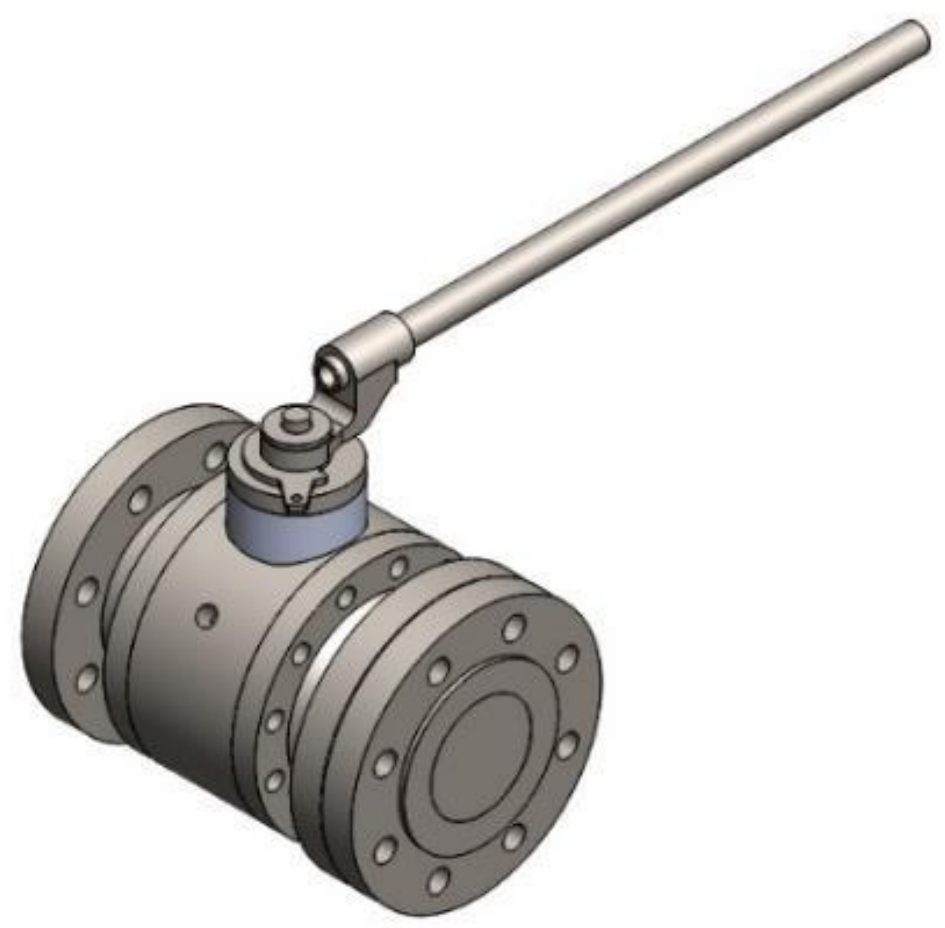

Gambar 1. Model Geometri Ball Valve 4"-300 Analisis Flange

Setelah proses penyederhanaan gambar maka dilanjutkan dengan proses meshing yaitu melakukan tahap analisis dengan bantuan Solidworks. Bentuk node atau nodalnya adalah trihedron. Hasil meshing model untuk dianalisis dapat dilihat pada Gambar 2. 


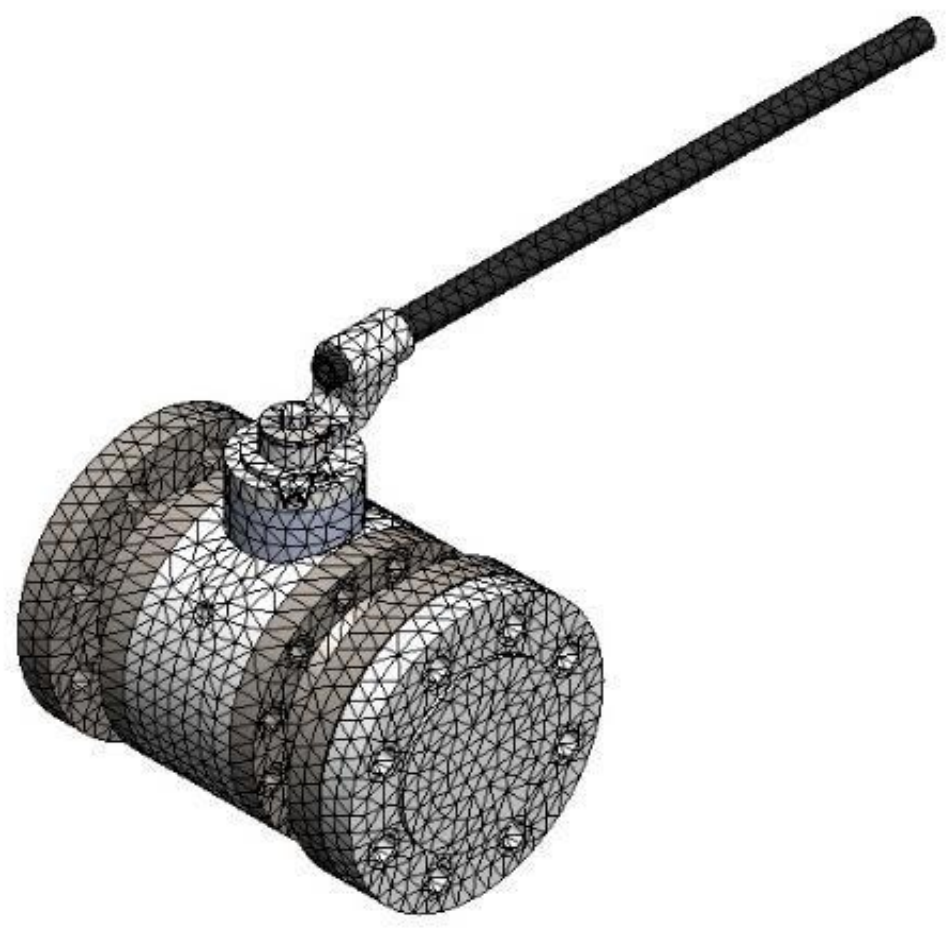

Gambar 2. Model Meshing Ball Valve 4"-300 analisis Flange

\subsection{Properti Material, Kondisi Batas dan Pembebanan}

Analisis kekuatan Flange Ball Valve dengan adanya tekanan dari fluida dalam sistem dan asumsi adanya Bolt Torque. Material flange sama dengan Body Ball Valve yaitu ASTM A105 Steel. Sedangkan material baut berdasarkan material sesuai dengan ASME B16.5, Class 300. Untuk jenis ball valve 4 inch -300, ukuran flange 4 inch, jumlah baut 8 dengan ukuran 3/4 inch. Torsi baut yang digunakan dipilih dengan pelumasan copperslip dengan koefisien gesek $(\mu=0.1)$ yaitu $120 \mathrm{lbf} . \mathrm{ft} / 165 \mathrm{Nm}$ [10][11].

Batas tumpuan untuk analisis flange ini adalah horizontal fix dengan pembebanan dari pressure dalam sistem dan temperatur fluida. Pembebanan yang diterima flange dari aliran fluida pada sistem dan Bolt Torque dengan asumsi $200 \mathrm{lbf}$.in untuk flange joint to pipe dan 100 lbf.in untuk flange joint to body. Bentuk kondisi batas dan pembebanan dapat dilihat pada Gambar 3. 
Analisis Kekuatan Flange Valve Akibat Pengaruh Bolt Torque pada Kondisi Pressure dan Temperature Berbeda dengan Metode Finite Element Analysis

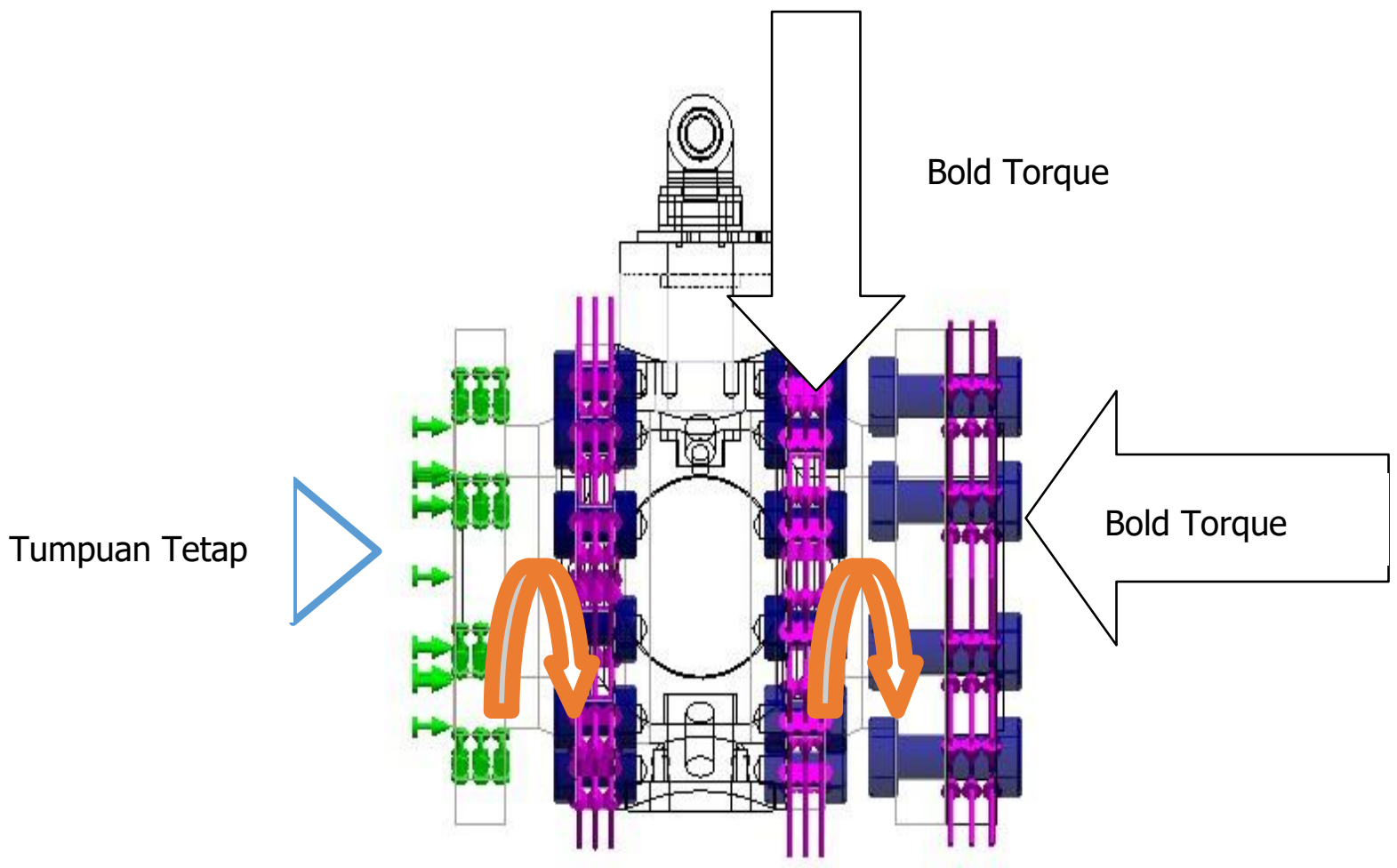

Gambar 3. Kondisi Batas dan Pembebanan

Setiap baut akan menerima beban torsi awal. Bentuk dan nilai pada metode analisis flange untuk setiap baut karena kondisi torsi dapat dilihat pada Gambar 4.

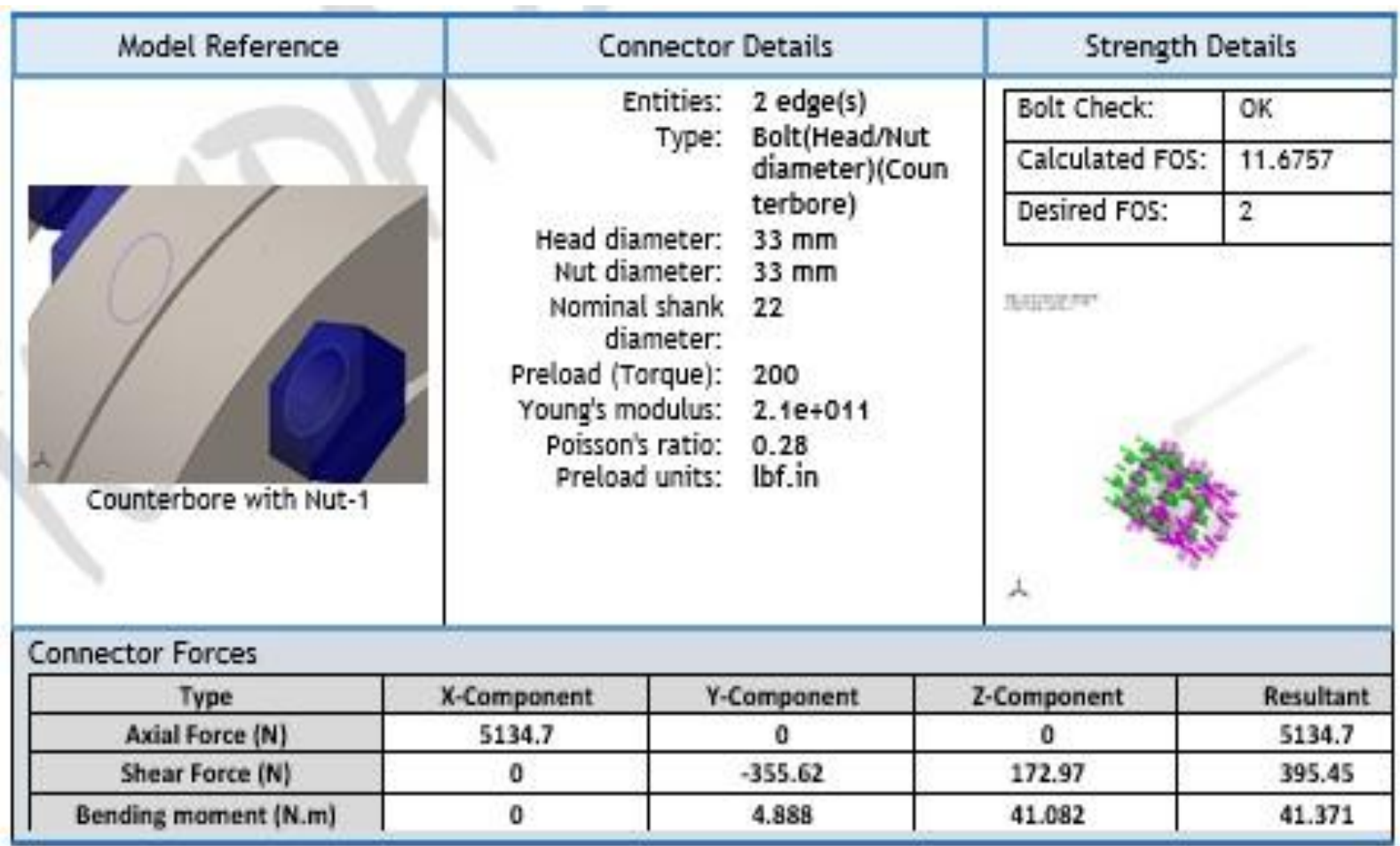

Gambar 4. Kondisi Pembebanan Preload (Torsi) 
Sedangkan kondisi perbedaan tekanan akibat fluida dan temperatur dibedakan menjadi tiga kondisi. Perbedaan tersebut dapat dilihat pada Gambar 5.

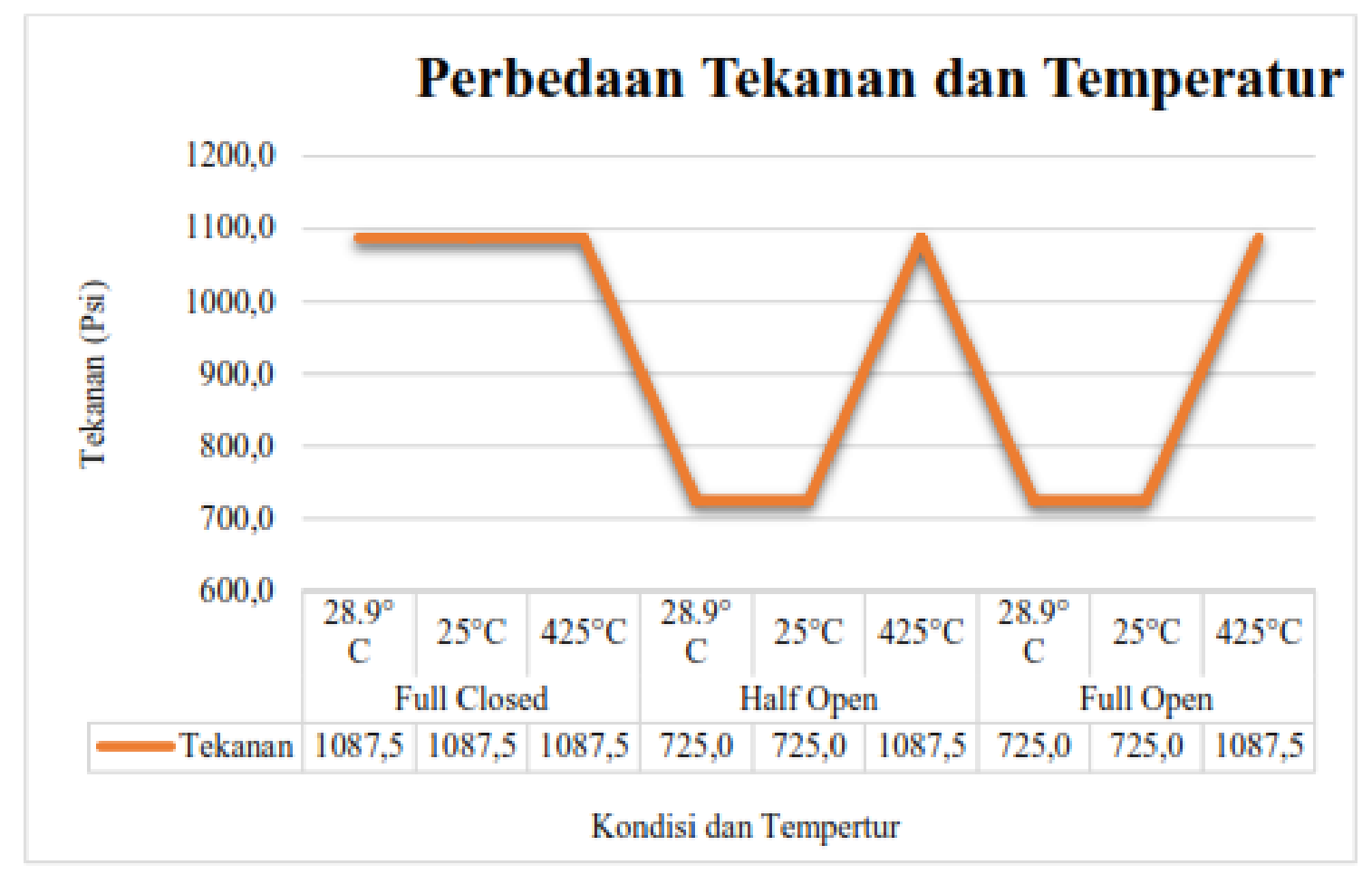

Gambar 5. Perbedaan Tekanan dan Temperatur (Rahmi, dkk (2018a, 2018b)

\section{HASIL DAN PEMBAHASAN}

Hasil Finite Element Analysis (FEA) pada flange ball valve 4 inch ANSI 300 dengan bantuan software Solid works dapat lihat pada Gambar 6, Gambar 7, juga terlihat pada Gambar 8 dan pada Gambar 9.
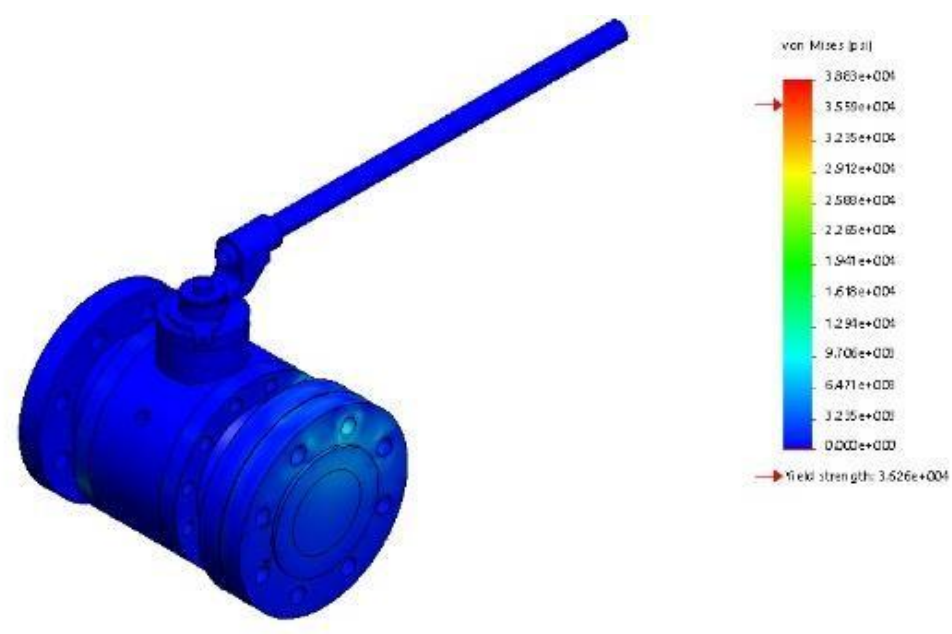
Analisis Kekuatan Flange Valve Akibat Pengaruh Bolt Torque pada Kondisi Pressure dan Temperature Berbeda dengan Metode Finite Element Analysis

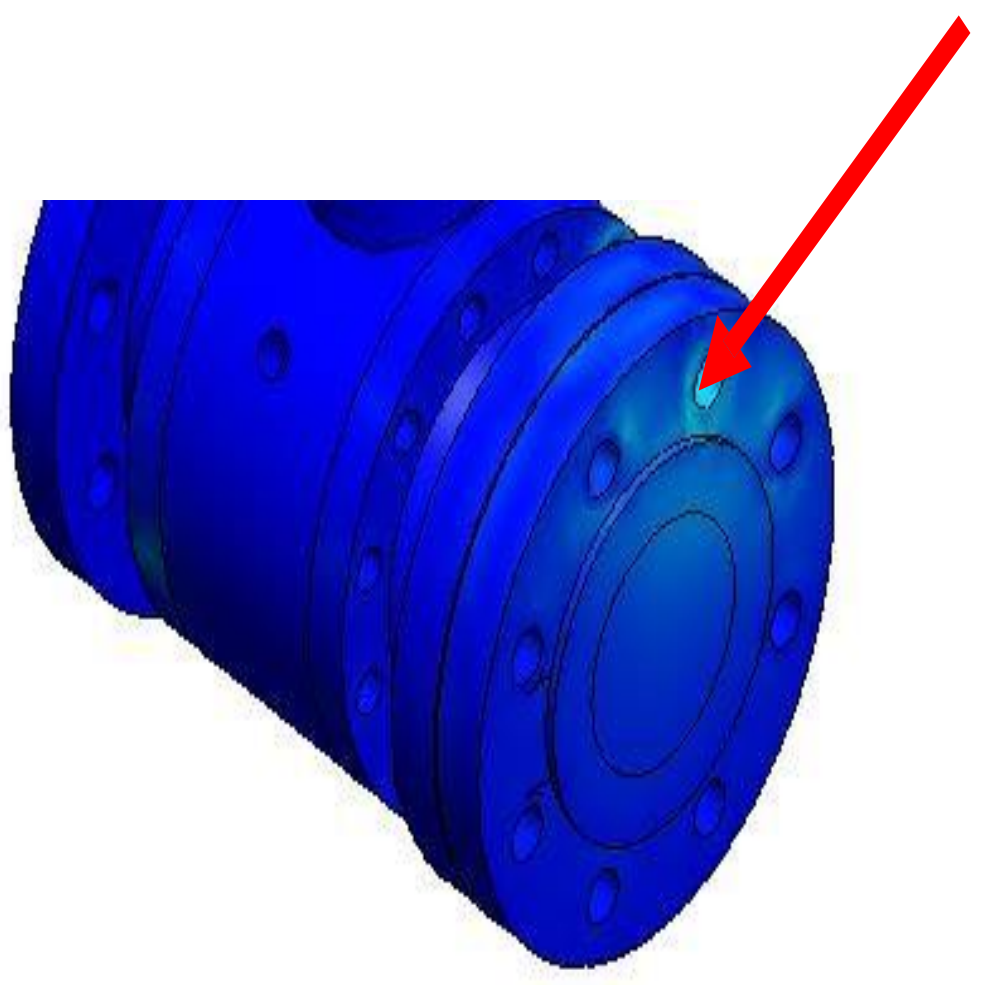

Gambar 6. Hasil Analisis Tegangan pada Flange

Hasil analisis pada Gambar 6 menunjukkan hasil tegangan yang terjadi pada flange akibat pengaruh pengencangan baut dengan torsi sesuai dengan ASME B16.5, Class 300 tidak signifikan mempengaruhi flange pada ball valve 4 inch -300 .
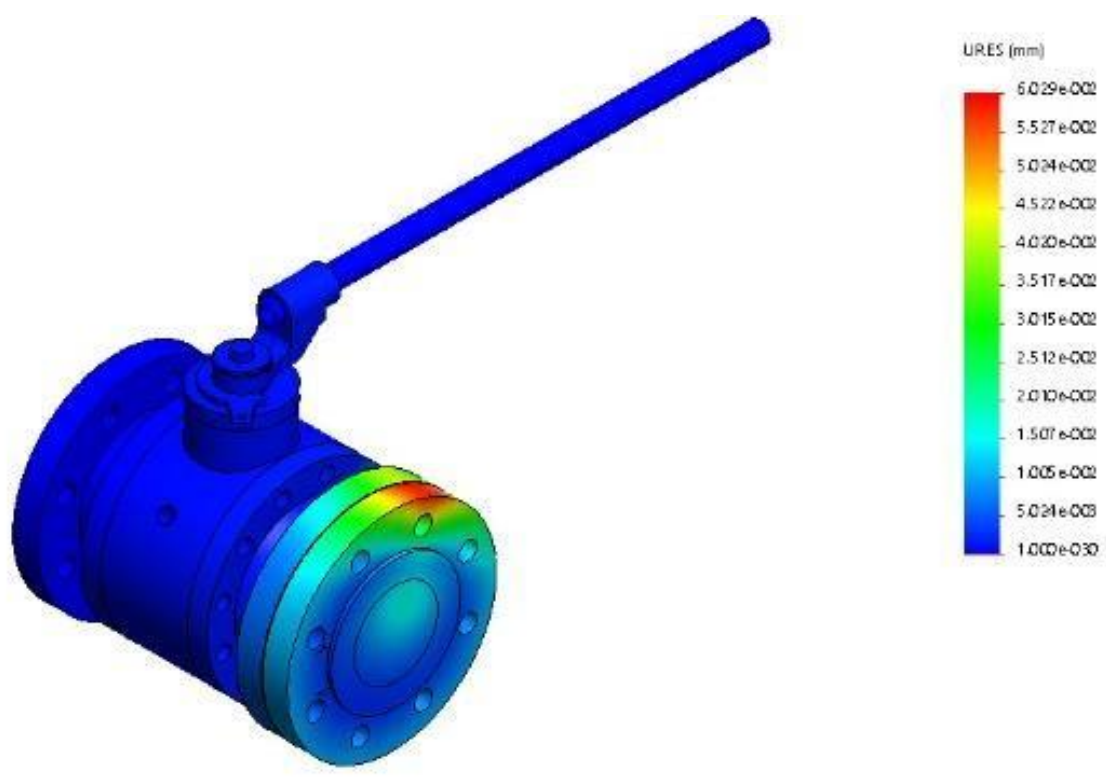
Meri Rahmi, Suliono, Delffika Canra, Rachmatullah, Yusuf Nur Rohmat, Dedi Suwandi

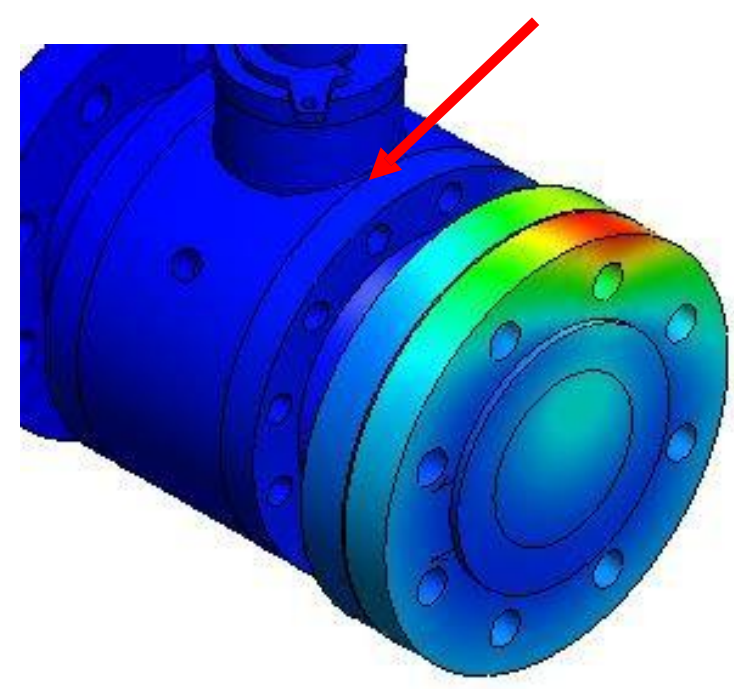

Gambar 7. Hasil Analisis Displacement pada Flange

Hasil analisis pada Gambar 7 menunjukkan hasil deformasi yang terjadi pada flange akibat pengaruh pengencangan baut dengan torsi sesuai dengan ASME B16.5, Class 300. Perubahan tidak signifikan mempengaruhi flange pada ball valve 4 inch - 300 yaitu 0.0602 $\mathrm{mm}$. Gambar 8 menunjukkan hasil regangan yang terjadi pada flange akibat pengaruh pengencangan baut dengan torsi sesuai dengan ASME B16.5, Class 300. Perubahan tidak signifikan mempengaruhi flange pada ball valve 4 inch - 300 yaitu $0.005 \mathrm{~mm}$.
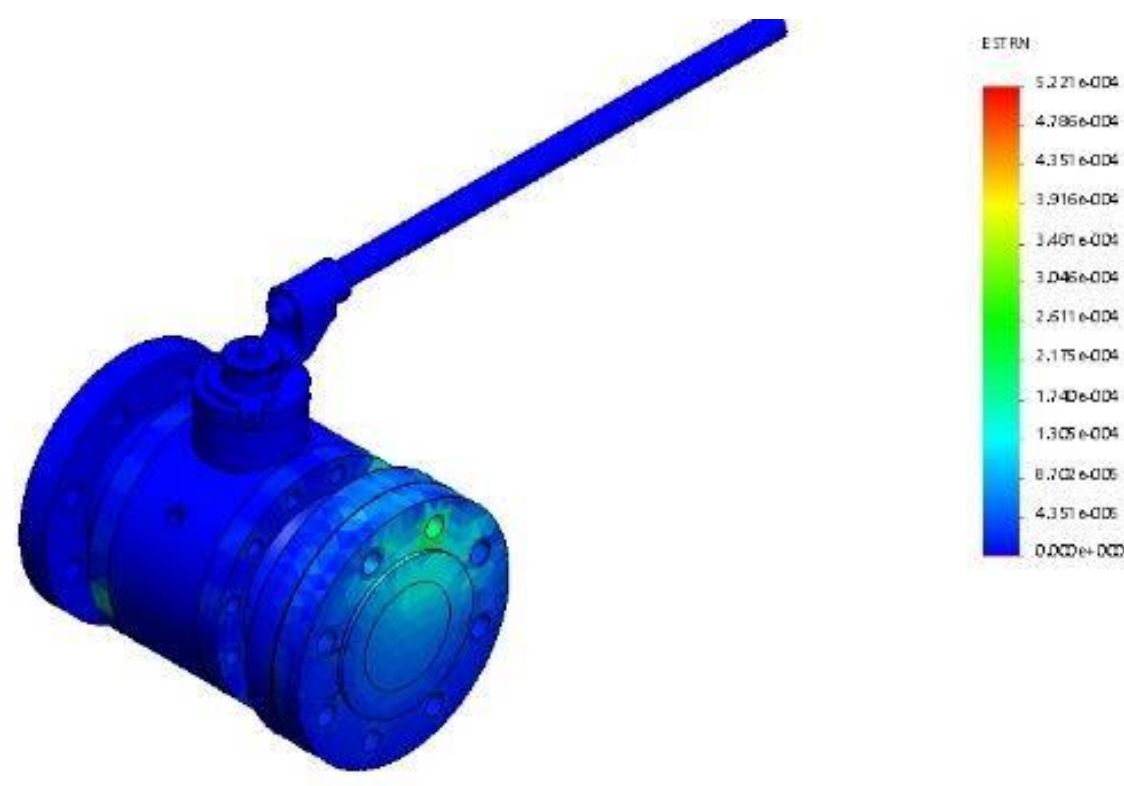
Analisis Kekuatan Flange Valve Akibat Pengaruh Bolt Torque pada Kondisi Pressure dan Temperature Berbeda dengan Metode Finite Element Analysis

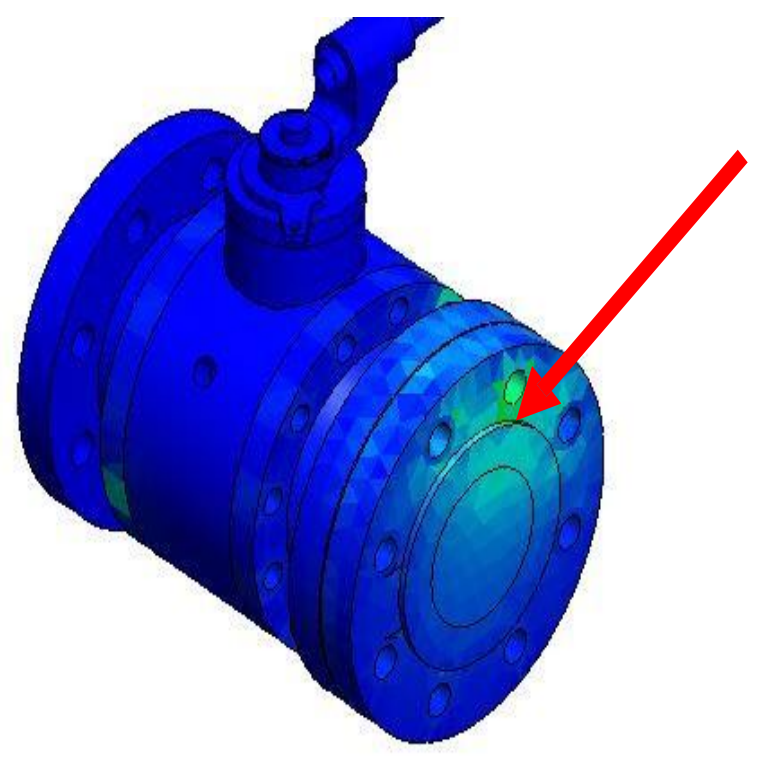

Gambar 8. Hasil Analisis Strain pada Flange

Gambar 9 menunjukkan hasil regangan yang terjadi pada flange akibat pengaruh pengencangan baut dengan torsi sesuai dengan ASME B16.5, Class 300. Perubahan tidak signifikan mempengaruhi flange pada ball valve 4 inch - 300 yaitu $0.005 \mathrm{~mm}$.
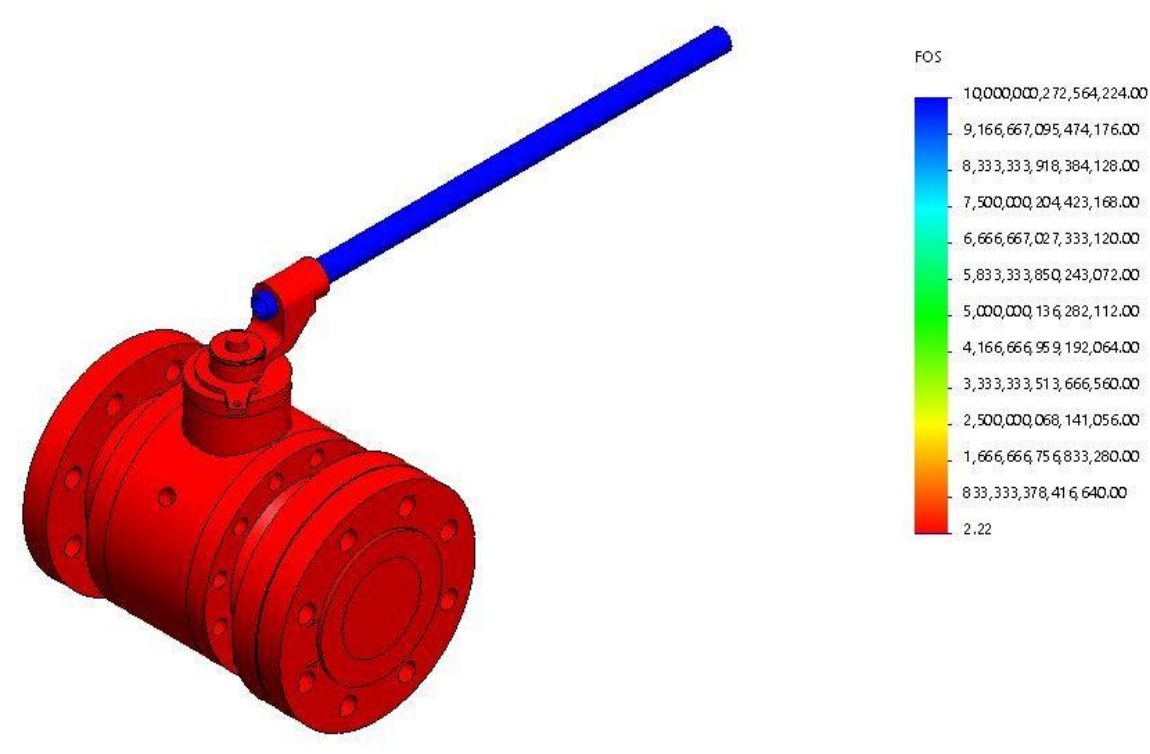

\section{KESIMPULAN}

Dari analisis kekuatan flange dengan adanya tekanan pressure fluida dalam sistem dan pengaruh Bolt Torque, disimpulkan bahwa flange kuat serta aman pada saat beoperasi sesuai dengan ASME B16.5, Class 300 pada ball valve 4 inch-300. Dengan berbagai kondisi batas dan pembebanan serta data material yang digunakan, dapat disimpulkan untuk ball valve 4 inch-300 ini comply dan aman. 
Meri Rahmi, Suliono, Delffika Canra, Rachmatullah, Yusuf Nur Rohmat, Dedi Suwandi

\section{REFERENSI}

[1] J, S., \& A.S, T. (1994). Pressure Vessel Design : Concepts and Principles. London, UK: Taylor \& Francis Routledge.

[2] Prihatnadi, H., \& Santoso, B. (2011). Analisa Kekuatan Flange Pada Sistem Pemipaan Primer Reaktor Triga 2000 Bandung. Jurnal Perangkat Nuklir, 36-41.

[3] Couchaux, M., Hjiaj, M., Ivor, R., \& Bureau, A. (2018). Tensile resistances of bolted circular flange connections. Engineering Structures, 817-841.

[4] Abid, M., Javed, S., Wajid, H. A., \& Nash, D. H. (2018). Performance Of A Gasketed Joint Under Bolt Up And Combined Pressure, Axial And Thermal Loading - Fea Study. International Journal of Pressure Vessels and Piping.

[5] Rahmi, M., Canra, D., \& Suliono. (2018). Analisis kekuatan ball valve akibat tekanan fluida menggunakan finite element analysis. Jurnal Teknologi Terapan , 4 Nomor 2, 79-84.

[6] Elliott, M., Teh, L., \& Ahmed, A. (2019). Behaviour and strength of bolted connections failing in shear. Journal of Constructional Steel Research, 320-329.

[7] Rahmi, M., Canra, D., \& Suliono, S. (2018). Analisis Perbedaan Tekanan Fluida pada Ball Valve Kondisi Full Closed dan Full Open dengan Computational Fluid Dynamics. JTT (Jurnal Teknologi Terapan), 1.

[8] Guo, Z., Lu, N., Zhu, F., \& Gao, R. (2017). Effect of preloading in high-strength bolts on bolted-connections exposed to fire. Fire Safety Journal, 112-122.

[9] Kumar a, S., \& Reddy b, D. (2017). Sustainability analysis of Bolted Joints through strength evaluation. Materials Today: Proceedings 4 -ICAAMM-2016, (pp. 7628-7635).

[10] Weigand, J., Peixoto, R., Vieira Jr, L. C., Main, J., \& Seif, M. (2018). An empirical component-based model for high-strength bolts at elevated temperatures. Journal of Constructional Steel Research, 87-102.

[11] Zhao, Z., Liang, B., Liu, H., \& Li, Y. (2018). Simplified numerical model for highstrength bolted connections. Engineering Structures, 119-127. 